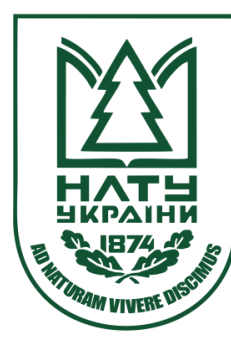

Науковий вісник НлтУ України Scientific Bulletin of UNFU

ISSN 1994-7836 (print)

https://nv.nltu.edu.ua

https://doi.org/10.15421/40280907

$@ \bowtie$ Correspondence author

Article received $15.10 .2018 \mathrm{p}$.

Article accepted 25.10.2018 p.

N. J. Minchak

удк 331.5.024

Н. Д. Мінчак, Г. В. Ожубко

Дрогобицький державний педагогічний університет ім. Івана Франка, Украӥна

\title{
ІНФОРМАЦІЙНО-МЕТОДИЧНЕ ЗАБЕЗПЕЧЕННЯ УПРАВЛІННЯ ПЕРСОНАЛОМ
}

Досліджено особливості застосування інформаційно-методичного забезпечення процесу управління персоналом підприємства. Обгрунтовано вплив інформаційного забезпечення на ефективність професійного навчання персоналу. 3'ясовано, що під інформацією розуміють сукупність даних, що зменшують рівень невизначеності знання про конкретний суб'єкт. Визначено, що інформація з розвитку персоналу повинна відповідати таким вимогам: повнота й точність, своєчасність та оперативність, корисність, об'єктивність, доступність, стислість, оброблення та зберігання. Розглянуто наукові підходи щодо інформаційної системи професійного навчання персоналу в контексті широкого застосування ЕОМ, сучасних інформаційних технологій, економіко-математичних методів та методів моделювання. Проаналізовано наукові дослідження і публікації щодо ефективності застосування інформаційних технологій в управлінні персоналом підприємства. Визначено, що основу інформаційної системи персоналу на підприємстві становить єдиний масив, що містить інформацію про кожного працівника. Запропоновано способи запровадження автоматизованого вирішення управлінських завдань. Досліджено технологію вирішення управлінських завдань за допомогою автоматизованих систем. Обгрунтовано, що інформаційне забезпечення (I3) $\epsilon$ з'єднувальним ланцюгом між функціональними можливостями системи управління і їх програмною реалізацією. Виокремлено окремі аспекти інформаційного, методичного і алгоритмічного забезпечення процесу управління кадрами.

Ключові слова: інформація; професійне навчання; система; ефективність; технологія; оперативна інформація; кадри; алгоритм.

Вступ. Для інформаційного суспільства характерне постійне нарощування обсягів виробництва, наданих послуг і збільшення обсягів інформації, якими має володіти працівник для того, щоб забезпечити власну конкурентоспроможність на ринку праці. Тому навчання персоналу відіграє важливу роль у системі управління підприємством. Сучасні інформаційні технології забезпечують оперативне отримання працівниками в процесі професійного навчання потрібної інформації за короткий проміжок часу з мінімальними витратами коштів. Поширення інтернет-комунікацій дає змогу персоналу підприємства обмінюватись професійним досвідом та іншою навчальною інформацією незалежно від їхнього місце знаходження. Особливо важливим $є$ використання інформаційних технологій в управлінні персоналом. Для вдосконалення системи управління персоналом та доведення iї у відповідно до інноваційного розвитку економіки доцільно створити механізм інформаційно-методичного забезпечення управління на підприємстві.

Аналіз останніх досліджень і публікацій. Дослідження цих проблем стосуються роботи багатьох вітчизняних і зарубіжних учених, серед яких найбільший інтерес становлять роботи Р. З. Каплана, Д. П. Нортона, А. Н. Тіщенко, Н. А. Кизіма, Я. В. Догадайло, В. М. Ко- лота, 3. А. Попова, І. І. Мазура, В. Д. Шапіро, Н. Г. Ольдерогге, А. Д. Шеремета, Р. С. Сайфуліна. Проте різні погляди, відображені в цих роботах, породжують щоразу більше спірних питань і виявляють суперечності. Тому ця проблема потребує подальшого вивчення. Відсутність такого механізму є однією з причин стагнації професійного навчання на підприємствах. Отже, метою роботи є дослідити застосування інформаційно-методичного забезпечення управління персоналом.

Викладення основного матеріалу. Інформаційне забезпечення професійного навчання персоналу на виробництві - це сукупність даних, що використовують суб'єкти професійного навчання для вирішення таких завдань, як: планування професійно-кваліфікаційної структури працівників підприємства, визначення додаткової потреби в робітниках і фахівцях, планування й організація самого процесу навчання персоналу, його мотивування та ін. (Potemkin, 1990).

Під інформацією розуміють сукупність даних, що зменшують рівень невизначеності знання про конкретний суб'єкт. Інформація позначає стан і визначає напрями змін і розвитку персоналу підприємства. Інформаційний процес управління розвитком персоналу передбачає перетворення вхідних даних, що містяться в документах з особового складу, типових і робочих нав-

Інформація про авторів:

Мінчак Нінель Джемалівна, канд. екон. наук, ст. викладач, кафедра економіки та менеджменту.

Email: rinaemerald2017@gmail.com

Ожубко Галина Володимирівна, канд. психол. наук, доцент, кафедра економіки та менеджменту. Email: Ozhubko.Galyna@gmail.com

Цитування за ДСту: Мінчак Н. Д., Ожубко Г. В. Інформаційно-методичне забезпечення управління персоналом. Науковий вісник НЛтУ України. Серія Економічна. 2018, т. 28, № 9. С. 40-43

Citation APA: Minchak, N. J., \& Ozhubko, G. V. (2018). Information and methodological support of personnel management. Scientific Bulletin of UNFU, 28(9), 40-43. https://doi.org/10.15421/40280907

40 Науковий вісник НлтУ України, 2018, т. 28, № 9 Scientific Bulletin of UNFU, 2018, vol. 28, no 9 
чальних планах і програмах, матеріалах і результатах соціологічних та інших видів досліджень, на інформацію, необхідну для прийняття рішень у сфері професійного навчання персоналу (Larin, 1997).

Інформація 3 розвитку персоналу має відповідати таким вимогам: повнота й точність, своєчасність та оперативність, корисність, об'єктивність, доступність, стислість, оброблення та зберігання. Необхідність збирання, зберігання, оброблення, аналізу та передавання різноманітної інформації з професійного навчання персоналу потребує створення на підприємствах належної інформаційної системи. Основу інформаційної системи персоналу на підприємстві становить єдиний масив, що містить інформацію про кожного працівника: місце роботи, демографічні дані, дані про освіту, ділові та особистісні якості, наявність професійної підготовки, сімейний стан, рух працівників на підприємстві, зміну професії, перепідготовку чи підвищення кваліфікації, атестацію та сертифікацію персоналу. Інформаційна система містить плани, програми, нормативно-правове забезпечення управління розвитком і використанням персоналу. Серед головних вимог, що висуваються до інформаційної системи професійного навчання персоналу, варто зазначити широке застосування ЕOM, сучасних інформаційних технологій, економіко-математичних методів, методів моделювання. Оскільки інформаційно-методичне забезпечення професійного навчання персоналу на підприємствах ще не відповідає сучасним вимогам, то ми внесли відповідні пропозиції щодо його поліпшення.

Упровадження автоматизованого вирішення управлінських завдань на практиці потрібно здійснювати за такою технологією:

1) здійснення аналізу існуючої на підприємстві системи управління (СУ) з погляду iї "придатності" в умовах застосування сучасних комп'ютерних технологій (у випадку придбання готових пакетів програм або їх проектуванні на замовлення);

2) методичне забезпечення завдань, обраних для розв'язання;

3) врахування інформаційних і алгоритмічних особливостей завдань, вирішення яких передбачають $з$ використанням НIT і їх впливу на управлінські процеси;

4) застосування можливостей щодо власного програмування, тобто самостійного створення програмного забезпечення;

5) упровадження, експлуатація і супровід відповідних пакетів програм.

Отож, тільки один з етапів цієї технології - проектування програм - $\epsilon$ прерогативою фахівців у галузі програмування і певною мірою (під час кодування алгоритмів) вважається технічною процедурою. Але оскільки кінцевим користувачем програмного продукту буде працівник сфери управління, то для нього є дуже важливими три попередніх етапи. Саме від якості їх виконання залежить і якість розробленого ПЗ, яке дає змогу (або не дає) застосувати його для прийняття об'єктивних, сучасних і оптимальних рішень. Розглянемо окремі аспекти інформаційного, методичного і алгоритмічного забезпечення процесу управління кадрами, які 3 одного боку дають змогу автоматизувати процес отримання управлінських рішень, а 3 іншого - їх використання для реалізації нових інформаційних технологій (НIT) вчиняє і зворотною дію на сутність управлінсь- ких завдань, а також на вирішення завдань стратегічного характеру - формування кадрової політики, зміну трудових процесів і структури зайнятості. Як зазначає М. В. Ларін, "Вище завдання управління - розроблення курсу подальшого розвитку фірми або організації... 3 розвитком інформаційних потоків виникла ситуація, єдиний вихід 3 якої $є$ передача частини функцій управління обчислювальним системам. Однак процес комунікації та механізми прийняття рішень на різних рівнях управління організаціями досліджені недостатньо. Це і становить основні труднощі у впровадженні ЕОМ в обробку інформації і для управління" (Larin, 1997). Ми погоджуємося $з$ такою оцінкою проблеми фахівцями.

3 погляду автоматизації, інформаційне забезпечення (I3) $є$ з'єднувальним ланцюгом між функціональними можливостями системи управління і їх програмною реалізацією. Саме від коректного уявлення якісного i кількісного складу вхідної і вихідної інформації залежить якість одержаних результатів. Вихідна і результативна інформації повинні задовольняти такі вимоги, як: мінімальність, оптимальність, достовірність, надійність і своєчасність. Усе це визначає час аналізу результатів і можливість прийняття оптимального рішення. Застосовуючи зазначені вимоги I3 до управління кадрами, потрібно мати на увазі, що до складу інформаційного забезпечення входять такі бази даних і знань: 1) трудове законодавство; 2) інструктивні та методичні матеріали міністерств і відомств; 3) нормативні акти державного і регіонального призначення; 4) сукупність документів нормативно-довідникового характеру, зокрема класифікатори загального значення (наприклад, спеціальностей за освітою, занять, професій робітників, посад службовців, спеціальностей вищої наукової кваліфікації, початкової професійної освіти, інформації про населення); 5) документи загальнодержавного і локального рівнів, які використовують для вирішення функціональних завдань (вхідні документи) і документи, які одержані внаслідок їх реалізації (вихідні документи); 6) інформаційна база у формі електронного еквіваленту; 7) інформаційна база про ринок праці; 8) інформаційно-довідникові та аналітичні матеріали мережі Інтернет із питань управління кадрами, управління персоналом, ринку праці, зайнятості та інших суміжних питань. Наводиться класифікація регламентів управління, серед яких виокремлені регламенти щодо інформаційного забезпечення. Вони охоплюють такі складові: організацію діловодства; типові форми документів; класифікатори довідників; положення про інформаційну систему; положення про банк даних; положення про службову таємницю (Pugachev, 1998).

Запропоновану класифікацію, на нашу думку, потрібно доповнити компонентами, що пов'язані 3 комп'ютерною реалізацією комплексу завдань будь-якої сфери управлінської діяльності, зокрема управління кадрами. До них варто віднести: 1) для традиційних інформаційних систем - бази даних (БД) і нерегламентовані форми документів, які отримують за системою запитів; 2) для систем 3 інтелектуальними компонентами - базу знань і базу цілей. Вирішення кадрових завдань можливе завдяки використанню обох зазначених компонентів. Причому, якщо першу з них досліджено і розроблено достатньо докладно (хоча і для обмеженої сукупності знань), то другу взагалі не охоплено жодним із відомих вітчизняних пакетів щодо управління кадра- 
ми. Однак, за прогнозами фахівців, значущість систем, заснованих на базах знань у майбутньому буде набувати дедалі більшого значення. Низка завдань у сфері кадрової діяльності мають неформалізований характер. Тому саме тут експертні системи (ЕС), елементами яких є база знань і база цілей, можуть набути найчастішого застосування, наприклад для вирішення завдань "Атестація персоналу", "Підтримка працездатного клімату в колективі" та ін. У самостійному варіанті ЕС використовують вже давно, зокрема в таких галузях, як: навчальні системи; системи, які виявляють психофізичні особливості особистості та колективу та ін. Однак у питаннях автоматизованого управління кадрами ці аспекти ще не набули широкого застосування (Martiusheva \& Kalyshenko, 2002).

На сьогодні у сфері управління склалась суперечлива ситуація: на фоні невпинного розвитку нових інформаційних технологій проявилася відсутність сучасних методів організації адміністративної діяльності, раціоналізація в галузі інформаційного забезпечення зводилася лише до деяких нововведень у рутинних процедуpax конторської праці. I ця проблема на підприємствах досі залишається невирішеною. Понад це, можна спостерігати два цікавих явища, які рухаються в паралельних напрямках. Перше - це розвиток нових інформаційних технологій. Друге - економічні умови, в яких постійно опиняються підприємства. Ті підприємства, які найбільш успішно справляються зі своїми економічними проблемами, можуть, відповідно, приділяти більше уваги і питанням упровадження в управлінський i виробничий процеси сучасних комп'ютерних технологій. У цьому випадку інформаційні й економічні процеси знаходять точку перетину і відбувається взаємне збагачення кожного з них. Удосконалення на базі нових інформаційних технологій управлінських процесів дає змогу приймати оптимальні рішення, які сприяють розвитку виробничої сфери. Інформаційну систему з управління розвитком і використання персоналу не можна розглядати як якийсь окремий блок. Інформаційна система повинна бути пов'язана 3 усіма блоками управління підприємством, оскільки вона комунікативно пов'язує всі складові системи управління. Так, для управління персоналом ними будуть бухгалтерський облік, трудові показники, планування i нормування. Складним $є$ те, що немає обгрунтованого складу кадрових завдань, які можуть бути переведені на вирішення за допомогою ЕОМ. Це - головна умова 3 обгрунтування складу інформації, що вимагається. Не менш проблемним $\epsilon$ те, що немає чіткої межі, до якого ступеня автоматизації повинно бути доведено вирішення тих або інших проблем, пов'язаних із персоналом. I тому кожне підприємство, виходячи із своїх можливостей і рівня кваліфікації працівників комп'ютерних підрозділів, самостійно формують необхідну інформацію.

Висновки. Отже, за допомогою відповідних методів дослідження і аналізу існуючого інформаційного забезпечення на підприємстві, зокрема в кадровій службі, можна вирішити багато проблем стосовно управління. Структурованість вихідної інформації допомагає достатньо легко організувати зберігання одержаних результатів в окремій базі даних. Такий підхід дає змогу надалі за необхідності звертатись до неї і проглядати аспекти досліджень, які цікавлять. Понад це, якщо дослідження системи управління і інформаційного забезпечення мають відносно регулярний характер, то наявність бази даних створить можливість для зіставлення аналогічних даних за різні періоди часу і цим самим простежувати динаміку змін в інформаційному забезпеченні, та навіть спрогнозує можливості його вдосконалення. Особливу цікавість може представляти подібна інформація для корпорації з метою удосконалення пї системи управління. Внаслідок застосування інформаційно-методичного забезпечення управління створено передумови для якісно нового підходу щодо управління розвитком і використанням персоналу, а саме: 1) більш ефективно вирішуються виробничі завдання між структурними підрозділами підприємства; 2) проведена оптимізація кількості документів, уніфікація їх структури, виключена надлишкова інформація у структурних підрозділах підприємства; 3) здійснена оптимізація інформаційних потоків; 4) забезпечена доступність довідників і класифікаторів посад, які використовують на підприємстві; 5) підвищилася ефективність пошуку інформації.

\section{Перелік використаних джерел}

Larin, M. V. (1997). Dokumentatcionnoe obespechenie i informatcionnyi menedzhment. Upravlenie personalom, 11, 43-47. [In Russian].

Martiusheva, L. S., \& Kalyshenko, V. O. (2002). Innovatsiinyi potentsial pidpryiemstva yak obiekt ekonomichnoho doslidzhennia. Finansy Ukrainy, 10, 61-66. [In Ukrainian].

Hrytsiuk, Yu. I., \& Zhabych, M. R. (2018). Risk Management of Implementation of Program Projects. Scientific Bulletin of UNFU, 28(1), 150-162. https://doi.org/10.15421/40280130

Potemkin, D. N. (1990). Otcenka i analiz ekonomicheskoi effektivnosti proizvodstva $\mathrm{v}$ usloviiakh ego intensifikatcii (na primere shinnoi promyshlennosti SSSR). Candidate Dissertation for Economic Sciences (08.00.05 - Development of productive forces and regional economy). Dnipropetrovsk, 491 p. [In Russian].

Pugachev, V. P. (1998). Rukovodstvo personalom organizatcii. Moscow: Aspekt-Press, 279 p. [In Russian].

Н. Д. Минчак, Г. В. Ожубко

Дрогобычский государственный педагогический университет им. Ивана Франко, г. Дрогобыч, Украина

\section{ИНФОРМАЦИОННО-МЕТОДИЧЕСКОЕ ОБЕСПЕЧЕНИЕ УПРАВЛЕНИЯ ПЕРСОНАЛОМ}

Исследованы особенности применения информационно-методического обеспечения процесса управления персоналом предприятия. Обосновано влияние информационного обеспечения на эффективность профессионального обучения персонала. Выяснено, что под информацией понимают совокупность данных, что уменьшают уровень неопределённости знания о конкретном субъекте. Определено, что информация по развитию персонала должна соответствовать таким требованиям, как: полнота и точность, своевременность и оперативность, полезность, объективность, краткость, обработка и сохранение. Рассмотрены научные подходы к информационной системе профессионального обучения персонала, в контексте широкого применения ЕВМ, современных информационных технологий, экономико-математических методов и методов моделирования. Проведён анализ научных исследований и публикаций по вопросу эффективности применения информационных технологий в управлении персоналом предприятия. Определено, что основу информационной системы персонала на предприятии составляет единый массив, который содержит информацию о каждом работнике. Предложены пути внедрения автоматизи- 
рованного решения управленческих задач. Исследована технология решения управленческих задач при помощи автоматизированных систем. Обосновано, что информационное обеспечение есть соединяющим звеном между функциональными возможностями системы управления и их программной реализацией. Выделены отдельные аспекты информационного, методического и алгоритмического обеспечения процесса управления кадрами. Рассмотрен системный поход к формированию эффективной системы информационно-методического обеспечения управления персоналом предприятия.

Ключевые слова: информация; профессиональное обучение; система; эффективность; технология; оперативная информация; кадры; алгоритм.

N. J. Minchak, G. V. Ozhubko

Drohobych Ivan Franko State Pedagogical University, Drohobych, Ukraine

\section{INFORMATION AND METHODOLOGICAL SUPPORT OF PERSONNEL MANAGEMENT}

The peculiarities of the usage of information and methodological support of personnel management process of the enterprise are investigated. The influence of information provision on efficiency of professional training of the personnel is grounded. It is revealed that information is understood as a collection of data that reduces the level of uncertainty of knowledge about a particular subject. It has been determined that information on personnel development should meet the following requirements: completeness and accuracy, timeliness and efficiency, utility, objectivity, accessibility, objectivity, conciseness, processing and storage. The scientific approaches to the information system of professional training of the personnel, in the context of the wide use of computers, modern information technologies, economical-mathematical methods and modeling methods are considered. The analysis of scientific researches and publications on the efficiency of the application of information technologies in the management of the personnel of the enterprise was conducted. The basis of the information system of the personnel at the enterprise is determined to be a single array containing information about each employee. The ways of implementing automated solution management problems. The technology of solving managerial problems with the help of automated systems is explored. It is substantiated that information support (IZ) is a connecting chain between the functional capabilities of the control system and their program implementation. Some aspects of informational, methodological and algorithmic provision of personnel management process are highlighted.

Keywords: information; professional training; system; efficiency; technology; operational information; personnel; algorithm. 